\title{
Leszek Koczanowicz
}

ORCID: 0000-0002-4204-1674

WSPS Wrocław

\section{Somaestetyka, władza cielesna i mikrofizyka emancypacji}

Abstrakt: Celem artykułu jest analiza oporu w stosunku do opresyjnej władzy w życiu codziennym z naciskiem na praktyki cielesne, które stają się narzędziem emancypacji. Artykuł eksploruje dwa ważne, lecz wciąż niedostatecznie interpretowane pola badawcze: ciało jako wehikuł krytyki społecznej i relacje między życiem codziennym a polityką. Oba te pola są analizowane poprzez dyskusje, które odbywają się we współczesnych naukach humanistycznych i społecznych. Umożliwia to odsłonięcie istniejących luk i sugerowanie, jak mogą być zapełnione. Główną tezą artykułu jest, że potrzebujemy adekwatnej koncepcji związków między ciałem i władzą, która może wyłonić się z tradycji pragmatycznej rozwijanej i wzbogacanej pod tym względem w neopragmatyzmie Richarda Shustermana.

Słowa-klucze: ciało, emancypacja, życie codzienne, polityka, kultura

W 1999 roku chiński rząd komunistyczny rozpoczął rozprawę z Falun Gong, ruchem mieszczącym się między sektą religijną a cielesnymi praktykami uzdrawiającymi. Ian Buruma w swoim komentarzu do tego wydarzenia w „New York Times" napisał:

Z historycznego punktu widzenia Falun Gong wygląda bardzo znajomo. Tajne stowarzyszenia, ruchy religijne i sekty uzdrawiające wiarę, oparte na połączeniu buddyzmu, taoizmu i tysiącletnich wierzeniach ludowych, były częścią chińskiej sceny od tysięcy lat. W czasach kryzysu i transformacji mają tendencję do wzrostu - i rosną gwałtownie ${ }^{1}$.

Charakterystyczne dla tego ruchu jest, że nigdy nie kwestionował on władzy komunistycznej, zamiast tego prezentował się jako przedsięwzięcie promujące dobrostan poprzez praktyki cielesne i duchowe medytacje. Buruma uznał Falun Gong za ostatnią inkarnację długiej linii wschodnich sekt, która łączyła ćwiczenia fizyczne z mniej lub bardziej rozwiniętym przekazem duchowym.

* Artykuł powstał w ramach grantu NCN-u nr 2018/29/B/HS2/00041 „Władza somatyczna i mikrofizyka emancypacji: w kierunku kultury wyzwolenia".

${ }^{1}$ I. Buruma, The Sect That Become an Enemy of the State, „New York Times” 25 July 1999.

Prace Kulturoznawcze 23, 2019, nr 1

(C) for this edition by CNS 
W żadnym razie jednak takie ruchy nie ograniczały się wyłącznie do Wschodu. Podobne tendencje można łatwo zaobserwować również na Zachodzie. Zwykle zaczynały bez żadnych politycznych celów, ale niektóre z nich zostały zmuszone do przyjęcia stanowiska politycznego w obliczu opresji ze strony państwa, jak to miało miejsce w przypadku Falun Gong. Takie ruchy z reguły były popularne wśród uciskanych, dawały im szansę na zmianę życia i osiągnięcie pewnego stopnia niezależności od swoich ciemiężców lub przynajmniej osiągnięcia złudzenia takiej niezależności. Czasami, podobnie jak w przypadku sztuk walki tak popularnych w wielu kulturach, samo ciało stało się instrumentem sprzeciwu wobec potęgi państwa poprzez przełamanie wyłącznego monopolu państwa na przemoc. W ten sposób takie ruchy uosabiały samą ideę emancypacji, jak na przykład capoeira - mieszanka rytuałów, tańca, gimnastyki i religii. Jak pisze Matthias Röhrig Assunção, autor książki o tym ruchu: ,Jednym z powodów, dla których capoeira fascynuje młodych ludzi na całym świecie, jest to, że nadal wydaje się uosabiać opór: przeciwko właścicielom niewolników, policji, establishmentowi"2.

W swoim artykule zamierzam skoncentrować się na problemie, w jaki sposób takie ruchy można konceptualizować w naukach społecznych i humanistycznych. Trudność polega na tym, że znajdują się na skrzyżowaniu dwóch ważnych, ale nigdy niewystarczająco zbadanych pól teoretycznych: ciała jako narzędzia krytyki społecznej, codzienności i polityki. Chciałbym zająć się tymi dwoma zagadnieniami, zaczynając od krótkiego przedstawienia dyskusji na ich temat, które są prowadzone we współczesnych naukach społecznych i humanistycznych. Umożliwi to zidentyfikowanie istniejących luk i pokazanie, przynajmniej w zarysie, jak można je wypełnić. Moją główną tezą jest, że potrzebujemy adekwatnej koncepcji relacji między ciałem a władzą i że może się ona wyłonić z tradycji filozofii pragmatycznej rozwijanej i udoskonalonej w tym aspekcie przez neopragmatyzm Richarda Shustermana.

Po przełomowych pracach Michela Foucaulta na temat biopolityki, biowładzy i mikrofizyki władzy raczej banalne jest mówienie o politycznym znaczeniu ciała. W pewnym sensie Foucault zmienił punkt ciężkości myśli politycznej, która musiała od tego momentu uwzględniać również cielesną stronę człowieka. Przed nim polityczna teoria była zaabsorbowana głównie czystymi ideami, w których ciało „wyparowało”, nawet jeśli istniało wyraźne odniesienie do ludzkiej fizyczności, jak na przykład w rewolucyjnym terrorze. Oczywiście nadal takie podejście jest dominujące $w$ wielu teoriach politycznych i społecznych, ale coraz bardziej docenia się znaczenie ciała dla zrozumienia polityki. Jednak jak pisze Thomas Lemke: „Dyscyplina nie jest formą indywidualizacji, której poddawane są jednostki, lecz zawsze zakłada pewną wielość. Tak samo ludność przedstawia sobą zrzeszenie

${ }^{2}$ M. Röhrig Assunção, Capoeira. The History of An Afro-Brazilian Martial Art, London-New York 2005, s. 2.

Prace Kulturoznawcze 23, 2019, nr 1

(C) for this edition by CNS 
i zespolenie bytów w nową polityczną formę"3. Strategia ta była oczywiście uzasadniona celem pracy Foucaulta, mianowicie pokazaniem szczególnych cech polityki w okresie nowoczesności, ale jednocześnie znacznie trudniej jest znaleźć więź między koncepcją biopolityki a koncepcją ciała społecznego ukształtowaną przez mechanizmy władzy.

Gdy jednak spróbujemy stworzyć takie połączenie, napotkamy dodatkowe kłopoty. Znaczenie pracy Foucaulta polega na ukazaniu, w jaki sposób ciała są kształtowane i kontrolowane przez władzę. Wielokrotnie zauważano, że problem z jego teorią polega na traktowaniu ciała niemal wyłącznie jako materiału pasywnego, który jest podporządkowany i uległy. Foucault w swoich ostatnich pracach wprowadził koncepcję technik siebie, która ukazuje ciało jako znacznie bardziej aktywne i sprawcze, ale jego działalność, która może przeciwstawić się dominującej władzy, nadal pozostaje bardzo indywidualistyczna, jako umożliwiająca

jednostkom dokonywać, za pomocą własnych środków bądź przy pomocy innych, pewnych operacji na własnych ciałach oraz duszach, myślach, zachowaniach, sposobie bycia, operacji, których celem jest przekształcenie siebie tak, by osiągnąć pewien stan szczęścia, czystości, mądrości, doskonałości czy nieśmiertelności ${ }^{4}$.

Dlatego nawet próby połączenia biowładzy z biopolityką, które nawiązują do myśli Foucaulta, odziedziczyły tę wadę. Przykładem może być wpływowy artykuł napisany przez Paula Rabinova i Nikolasa Rose’a, w którym biowładza została zdefiniowana następująco:

koncepcja biowładzy stara się oddzielić strategie i konfiguracje, które łączą trzy wymiary czy plany - forma dyskursu prawdy dotyczącego żywych istot i ciągu autorytetów, które są uważane za kompetentne, by mówić tę prawdę; strategie interwencji w kolektywne istnienie w imieniu życia i zdrowia oraz sposoby upodmiotawiania, w których jednostki mogą być skłonione do pracy nad sobą, respektując pewne formy autorytetu, poprzez praktyki siebie, w imieniu jednostkowego lub kolektywnego życia lub zdrowia ${ }^{5}$.

Chociaż podejście to zaowocowało wieloma interesującymi pracami nad wzmocnieniem pozycji pacjentów w systemie opieki zdrowotnej, szczególnie tych z grup uciskanych, nie rozszerzyło jednak pola ogólnej teorii społecznej.

Istnieją, jak sądzę, dwa główne powody tego stanu. Po pierwsze, zniekształcony obraz relacji między polityką a życiem codziennym panujący w humanistyce i naukach społecznych. Po drugie, brak odpowiedniej koncepcji ciała, która mogłaby łączyć charakter społeczny cielesności z uznaniem jej potencjału emancypacyjnego. Rozpatrzę osobno każdy z tych aspektów.

W dziedzinie badań nad życiem codziennym obserwujemy szybko rosnącą liczbę prac dotyczących różnych jego aspektów od historii po socjologię i kultu-

${ }^{3}$ T. Lemke, Biopolityka, przeł. T. Dominiak, Warszawa 2010, s. 47.

${ }^{4}$ M. Foucault, Techniki siebie. Czym jest Oświecenie?, przeł. D. Leszczyński, L. Rasiński, Warszawa 2000, s. 249.

5 P. Rabinov, N. Rose, Biopower Toda, „BioSocieties” 1, 2006, s. 203-204.

Prace Kulturoznawcze 23, 2019, nr 1

(C) for this edition by CNS 
roznawstwo. Nie ma jednak wystraczająco opracowanej koncepcji politycznego znaczenia codzienności.

Istnieją trzy modele relacji między codziennością a polityką. Pierwszy to radykalna separacja. W tym modelu polityka jest autonomiczną sferą niedającą się zredukować do jakichkolwiek innych elementów życia społecznego. Często ten niezależny aspekt polityki jest konceptualizowany przez podział między polityką a politycznością ( $\mathrm{w}$ języku francuskim la politique, le politique). Różnica ta została jasno sformułowana w przełomowym artykule Paula Ricoeura Paradoks polityczny:

alienacja polityczna nie daje się sprowadzić do żadnej innej, ale jest konstytutywna dla ludzkiej egzystencji, i w tym sensie polityczny tryb istnienia pociąga za sobą podział między abstrakcyjnym życiem obywatela a konkretnym życiem rodziny i pracy ${ }^{6}$.

Chociaż w teorii społecznej możemy znaleźć liczne konceptualizacje podziału politycznego (Carl Schmitt, Hannah Arendt, Claude Lefort, Chantal Mouffe i inni) z różnymi waloryzacjami, mają one wspólną cechę: przyjmują taką koncepcję polityki, która zakłada, że polityka jest autonomiczną sferą życia społecznego, która sytuuje się ponad życiem codziennym.

Niezależnie jednak od tego, jak oddzielamy politykę od codzienności, oczywiste jest, że presja polityczna wywierana jest $\mathrm{w}$ drobnych przyziemnych czynnościach. Skrajnymi przypadkami takiego wpływu są oczywiście reżimy totalitarne z ich obsesją kontroli, ale nawet w społeczeństwach demokratycznych zmiany polityczne mogą zmienić codzienne czynności. Dowody wpływu polityki na życie codzienne, zwłaszcza takie, które powszechnie uważano za jawnie niesprawiedliwe, położyły fundament pod tym, co chciałbym nazwać „krytyką codziennego życia”. Jak mówi Henri Lefebvre:

W życie codzienne włączone jest życie polityczne: świadomość publiczna, świadomość należenia do społeczeństwa i narodu, świadomość klasowa. Dzięki administracji i biurokracji życie codzienne stale styka się z państwem i jego aparatem. Z drugiej strony jednak życie polityczne oddzielone jest od życia codziennego poprzez koncentrację na szczególnych momentach (choćby wybory) i poprzez promowanie szczególnej działalności. Dlatego też krytyka życia codziennego zaktada krytykę życia politycznego w tym, że codzienne życie zawiera i konstytuuje taka krytykę: że jest taką krytyką ${ }^{7}$.

Ten typ krytyki był szeroko rozpowszechniony po lewej stronie spektrum politycznego, poczynając od przełomowej pracy Fryderyka Engelsa Położenie klasy robotniczej w Anglii i Rękopisów Karola Marksa ${ }^{8}$.

${ }^{6}$ P. Ricoeur, The Political Paradox, [w:] idem, History and Truth, przeł. Ch.A. Kelbley, Evanston 2007, s. 260.

${ }^{7}$ H. Lefebvre, Critique of Everyday Life, przeł. J. Moore, London-New York 2014, s. 114.

${ }^{8}$ F. Engeles, Położenie klasy robotniczej w Anglii, przeł. A. Długosz, Warszawa 1952; K. Marks, Rękopisy ekonomiczno-filozoficzne z roku 1844, przeł. K. Jażdżewski, T. Zabłudowski, [w:] K Marks, F. Engels, Dzieta, t. 1, Warszawa 1960.

Prace Kulturoznawcze 23, 2019, nr 1

(C) for this edition by CNS 
Ostatnio Pierre Bourdieu w swojej monumentalnej twórczości pokazał, jak podziały klasowe kształtują niemal wszystkie cechy życia codziennego, w tym także ciało, co oddaje wprowadzana przez niego kategoria habitusu. Francuski socjolog pokazał przekonująco, że podziały klasowe odnoszą się do wszelkich dziedzin życia społecznego, w tym także ciała. Tego typu krytyka ma bez wątpienia ogromne znaczenie, obciążona jest jednak także poważną wadą. Skupia się na reprodukcji nierówności społecznych i właściwie niewiele pozostawia nadziei na zmianę sytuacji.

Ludzie są jednak nie tylko obiektem reprodukcji struktur społecznych, lecz także odnosząc się do swych codziennych doświadczeń życiowych, mogą rozwinąć krytyczne nastawienie do istniejącego porządku społecznego. Luc Boltanski jest chyba najważniejszym socjologiem, który pokazał, jak działa taka krytyka. Główne punkty jego koncepcji prezentuje poniższa tabela.

\begin{tabular}{|l|l|}
\hline Krytyka & Potwierdzenie \\
\hline Aktorzy (działający) & System \\
\hline Ciało & Bezcielesna instytucja \\
\hline Osobista & Jako rzecznika \\
\hline Źródło: olśnienie & Źródło: rytuał \\
\hline Domyślny ekwiwalent krytyki: ironia/dystans & $\begin{array}{l}\text { Emocje na poziomie indywidualnym (wspól- } \\
\text { notowe spotkania) }\end{array}$ \\
\hline
\end{tabular}

Źródło: opracowanie własne na podstawie L. Boltanski, On Critique: A Sociology of Emancipation, przeł. G. Elliott, Cambridge 2011.

W tej tabeli łatwo zauważyć, że krytyka według Boltanskiego opiera się na jednostkowości, która sprzeciwia się systemowi, bezcielesnej instytucji. Jednostkowość, która jest nieuchronnie powiązana z ciałem i która jest zanurzona w codzienności, może przeciwstawiać się wszechobecności porządku instytucjonalnego. Boltanski ma rację, dostrzegając, że rytualizacja ładu instytucjonalnego może również przejść przez cielesność, poprzez emocje, które mają budzić rytuał. Ta strategia może działać przez jakiś czas, ale jak uczy nas totalitarne doświadczenie, przestaje ona wywierać swój urok, gdy w pewnym momencie zostaje skonfrontowana z testami egzystencjalnymi, które odgrywają znaczącą rolę w koncepcji krytyki Boltanskiego: są one

oparte na doświadczeniach, takich jak doświadczenia niesprawiedliwość lub upokorzenie, czasem skojarzone ze wstydem, ale także w innych przypadkach na radości, jaką daje transgresja, gdy zapewnia dostęp do jakiejś formy autentyczności ${ }^{9}$.

${ }^{9}$ Ibidem, s. 107.

Prace Kulturoznawcze 23, 2019, nr 1

(C) for this edition by CNS 
Koncepcja krytyki Boltanskiego, jedynie tu zarysowana, przynosi wiele pytań, na które trzeba odpowiedzieć, szczególnie związanych z ograniczeniami krytyki życia codziennego. Taka krytyka według niego ma ograniczony potencjał, ponieważ trudno ją zuniwersalizować. Wydaje się jednak, że musi ona być źródłem wszelkiego rodzaju krytyki społecznej, jeśli ta ostatnia ma być skuteczna. Dla poruszanego problemu najważniejszą kwestią jest to, w jakim stopniu cielesne/ wisceralne/emocjonalne reakcje mogą być narzędziem krytyki, ale także w jakim stopniu aktywność cielesna może być narzędziem emancypacji, przynajmniej na poziomie indywidualnym.

Jeśli chcemy zdefiniować emancypację na tym poziomie, musimy wypowiedzieć się na temat samej emancypacji. Emancypacja musi być rozumiana nie tylko jako pewien ogólny ruch ku większej wolności i/lub równości, ale także jako zbiór codziennych czynności, które umożliwiają ludziom uzyskanie większej autonomii w ich realnych stosunkach społecznych. Ten ostatni aspekt życia społecznego i politycznego, który nazywam „mikrofizyką emancypacji”, jest w dużej mierze pomijany przez ekspertów z dziedziny polityki. Mają oni tendencję do koncentrowania się na „wielkich” sprawach związanych z walką o władzę. Jednocześnie uczeni, zajmujący się historią lub kulturą życia codziennego, są zwykle zainteresowani wpływem polityki na życie codzienne, a nie odwrotnie. Ta sytuacja w teorii społecznej wzmacnia popularność ,podziału politycznego" między polityką a tym, co polityczne (politycznością). Chociaż podział ten rzeczywiście pomaga uwypuklić konfliktowy charakter sfery publicznej i prywatnej, utrudnia jednak zrozumienie potencjału tkwiącego w dialogu i współpracy, bez którego społeczeństwo jako takie po prostu nie może istnieć.

Ta „mikrofizyka emancypacji” może mieć wiele twarzy, które zostały na przykład opisane w książce Jeffa Goldfarba Polityka rzeczy małych ${ }^{10}$, poświęconej opozycji kulturalnej w komunistycznej Polsce lub w badaniach Li Bennich-Björkmana nad oporem egzystencjalnym w krajach bałtyckich i na Ukrainie Zachodniej. Mówiąc ogólnie, taka emancypacja nie ma charakteru politycznego, jest apolityczna, a nawet antypolityczna, a jej upolitycznienie następuje wtórnie pod presją państwa totalitarnego. Goldfarb na przykład opisuje niespodziewane miejsca wolności takie jak kuchnia w małym polskim mieszkaniu, gdzie zbierali się przyjaciele, aby otwarcie dyskutować kwestie polityczne. Pokazuje, że różne kulturalne wydarzenia, jak festiwale teatralne pozornie niemające charakteru politycznego, otwierały przestrzenie wolności, co przyczyniło się znacząco do powstania ruchu „Solidarności” w roku 1980.

Wśród różnych form mikroemancypacji wyjątkowe miejsce zajmują praktyki cielesne. Możemy uchwycić tę specyfikę tylko wtedy, gdy spojrzymy na wspomniane teorie ciała, które podkreślają jego społeczną konstrukcję, ale wraz

10 J. Goldfarb, Polityka rzeczy matych. Siła bezsilnych w mrocznych czasach, przeł. U. Lisowska, K. Liszka, A. Orzechowski, Wrocław 2012.

Prace Kulturoznawcze 23, 2019, nr 1

(C) for this edition by CNS 
z jej potencjałem emancypacyjnym. Współcześnie można wymienić trzy różne, acz powiązane $\mathrm{z}$ sobą, konceptualizacje ciała we współczesnych naukach humanistycznych i społecznych. Pierwsza z nich wyłania się z fenomenologicznych badań Maurice'a Merleau-Ponty'ego, które bezsprzecznie stanowią przełom w filozoficznych badaniach nad ciałem ${ }^{11}$. Jednakże intepretuje on ciało raczej w kategoriach percepcji niż działania. Dlatego też jego znaczący dorobek ma ograniczoną użyteczność w badaniach nad ciałem jako wehikułem emancypacji, choć inspirował interesujące rozważania z zakresu filozofii medycyny ${ }^{12}$. Druga tendencja koncentruje się na politycznej i społecznej konstrukcji ciała. W tym zakresie wspomniane prace Michela Foucaulta mają ogromne znaczenie. Wskazał on przekonująco, że ciało jest celem społecznego zniewolenia. Co więcej, połączył on koncepcję ciała społecznego ze swoją koncepcją wszechobecnej władzy, która przenika wszelkie relacje społeczne. Do pewnego stopnia można uzupełnić koncepcję ciała Michela Foucaulta tą, którą przedstawił Pierre Bourdieu, badając sposoby, w jakie ciało jest kształtowane przez podziały klasowe. Używane przez niego kategorie habitus i helis służą jako narzędzie analizy, jak na codzienne praktyki cielesne wpływa miejsce, które jednostka zajmuje w przestrzeni społecznej ${ }^{13}$. Niemniej obaj myśliciele, pomimo znaczenia ich koncepcji, postrzegają ciało raczej jako pasywny przedmiot wpływu społecznego.

$\mathrm{Z}$ mojego punktu widzenia najważniejsze jest pragmatyczne pojęcie ciała sformułowane przez Johna Deweya i George'a Herberta Meada, a rozwinięte przez Shustermana. Zarówno Dewey, jak i Mead w swych wczesnych pracach wykazali przekonująco, że w szerokim sensie nasze zjawiska mentalne są jedynie momentami w skomplikowanej koordynacji między organizmem a jego otoczeniem, która nie ma znaczenia wyłącznie adaptacyjnego, ale jest przede wszystkim złożonym procesem interakcji, w których organizm jest w stanie zmienić swoje otoczenie, a także samego siebie. W swej dojrzałej twórczości pokazali mechanizmy, dzięki którym ciało radzi sobie ze swym środowiskiem. Dewey w swojej psychologii społecznej pokazuje, jak działają inteligentne nawyki cielesne, aby ponownie budować nasze relacje z otoczeniem społecznym. Mead opracował skomplikowaną teorię jaźni społecznej, która zaczyna się od biologicznych koordynacji poprzez gesty. Ponadto Dewey w swoich późnych latach zainteresował się metodą Alexandra, w której zobaczył sposób na poprawę jakości życia poprzez praktyki cielesne.

Dewey i Mead niewątpliwie położyli podwaliny pod koncepcję ciała aktywnego i społecznego, ale dopiero Shusterman w swoich licznych pracach przedstawił pojęcie ciała, które może stać się wehikułem emancypacji. Shusterman nawiązuje do klasycznego pragmatyzmu, przede wszystkim Deweya. W swym eseju o De-

${ }^{11}$ M. Merleau-Ponty, Fenomenologia percepcji, przeł. J. Migasiński, M. Kowalska, Warszawa 2017.

12 D. Leder, The Absent Body, Chicago 1990.

${ }^{13}$ P. Bourdieu, Dystynkcja. Społeczna krytyka władzy sądzenia, przeł. P. Biłos, Warszawa 2006. 
weyowskiej koncepcji ciała (Odnowienie somatycznej refleksji. Filozofia ciało-umysłu Johna Deweya) wskazuje na aktualność koncepcji Deweya, która wynika choćby z tego, że rozwijał on koncepcję ciała nie tylko w wyniku filozoficznych spekulacji, lecz także poprzez dokładne śledzenie osiągnięć nauki i osobiste doświadczenia ze stosowaniem metody Alexandra. Shusterman zdaje sobie sprawę z wad koncepcji Deweya, które sprawiają, że wymaga ona korekty. Dostrzega on kłopotliwą sprzeczność zawartą w tej filozofii:

\begin{abstract}
Musimy polegać na nierefleksyjnych uczuciach i nawykach — ponieważ nie potrafimy pomyśleć o wszystkim i ponieważ owe nierefleksyjne uczucia i nawyki zawsze ugruntowują sam wysiłek naszej refleksji. Nie możemy jednak tym samym całkowicie na nich polegać, ani na sądach, które generują, ponieważ niektóre z nich są nieprecyzyjne lub pełne wad. Ponadto, jak moglibyśmy odkryć ich wady i niedoskonałości, gdy są one ukryte w swojej nierefleksyjnej, bezpośredniej, nawykowej formie, i jak moglibyśmy je poprawić, gdy nasze świadome, refleksyjne wysiłki zmierzające do ich modyfikacji, w sposób spontaniczny uzależnione są od tych samych niedokładnych, nawykowych mechanizmów percepcji i działania, które chcemy poprawić? ${ }^{14}$
\end{abstract}

W tekście, który cytowałem, Shusterman nie daje ostatecznej odpowiedzi na ten dylemat, ale zauważa, że mimo ogromnego postępu technologicznego i tak jesteśmy znacząco uzależnieni od stanu naszych ciał, które z kolei wpisane są w społeczne i kulturowe praktyki.

W poszukiwaniu inspiracji dla swych badań amerykański filozof zwraca się też do chińskich filozofów, takich jak Konfucjusz i Mencjusz, wskazując, że dowodzili oni, że postęp naszych zdolności umysłowych jest ściśle powiązany z funkcjonowaniem naszej cielesności. Te różne źródła jednak dzielą wspólne przekonanie, że im bardziej koncentrujemy się na poznawaniu naszej cielesności, tym bardziej zdajemy sobie sprawę z tego, że ciało nie może być rozpatrywane w oderwaniu od środowiska zarówno naturalnego, jak i społecznego, w którym się rozwija i przekształca. Dlatego też praca nad ciałem, nad jego lepszym funkcjonowaniem może prowadzić do lepszych relacji z otoczeniem, jak też do lepszego samo-rozumienia. Shusterman konkluduje więc:

Umożliwiając nam odczuwanie naszego uniwersum w większym wymiarze i z większą przenikliwością, świadomością i zrozumieniem, owa wizja somestetycznego kształtowania zapewnia najbogatsze i najgłębsze doznania doświadczalnych spełnień, może bowiem czerpać z obfitości kosmicznych zasobów, wliczając w to wzniosły sens kosmicznej jedności. Zachwycające intensywnością doświadczenia można tym samym osiągnąć w codziennym życiu, bez potrzeby stosowania drastycznych środków zmysłowej stymulacji, które zagrażają nam samym i innym. A jeśli nadal wybieramy niebezpieczne psychosomatyczne eksperymenty zwiększania skrajnej intensywności, nasza somaestetycznie rozwinięta zmysłowa świadomość powinna nas ostrzec przed bliskim ryzykiem oraz wprawić w unikaniu bądź zmniejszaniu wymiaru szkód ${ }^{15}$.

${ }^{14}$ R. Shusterman, Odnowienie somatycznej refleksji. Filozofia ciało-umystu Johna Deweya, [w:] idem, Świadomość ciała. Dociekania z zakresu somaestetyki, przeł. W. Małecki, S. Stankiewicz, Kraków 2009, s. 279.

15 Ibidem, s. 284.

Prace Kulturoznawcze 23, 2019, nr 1

(C) for this edition by CNS 
W swych następnych artykułach i książkach Shusterman pokazuje, jak różne praktyki cielesne mogą wpływać na poprawę naszego życia, refleksji nad tą sferą ma służyć nowa, stworzona i rozwijana przez niego dyscyplina wiedzy — somaestetyka. W swej ostatniej książce pisze o niej następująco:

Oprócz skierowania dociekań estetycznych na inne tory, somaestetyka pragnie również przekształcić filozofię w bardziej ogólny sposób. Somaestetyka scala mianowicie teorię i praktykę na drodze zdyscyplinowanych ćwiczeń somatycznych, przez co prowadzi filozofię w postulowanym przez pragmatyzm meliorystycznym kierunku, przywołując przy tym starożytną ideę filozofii jako ucieleśnionego sposobu życia raczej dyskursywnego ledwie uprawiania abstrakcyjnej teorii ${ }^{16}$.

Jeśli uznamy taki emancypacyjny potencjał ciała, możemy próbować konstruowania koncepcji władzy cielesnej (somapower), która odpowiadałaby na potrzeby ciała, a jednocześnie wykazywałaby na twórczy potencjał ciała. Taka koncepcja odwoływałaby się zarówno do biowładzy Foucaulta, jak i do pojęcia somaestetyki Shustermana. Ciało jest w niej traktowane jako miejsce władzy, ale jednocześnie może rzucić wyzwanie tej władzy i w tym sensie ma ono potencjał emancypacyjny. W pewnym sensie władza cielesna byłaby liminalnym przypadkiem somaestetycznego programu Shustermana. W tym kontekście możemy mówić o możliwościach, gdy aktywność cielesna wchodzi w kolizję z opresyjną władzą, a praktyki somatyczne stają się emblematem emancypacji. Szczególne miejsce władzy cielesnej wśród innych praktyk emancypacyjnych życia codziennego jest zapewnione przez jej konkretność; jej sprzeciw wobec wszelkich form abstrakcyjnej ideologii. Na tę cechę cielesnego doświadczenia zwracano już uwagę, wskazując, że może być ono użyte do krytyki ideologii uzasadniających opresję, jak też dzięki niemu dokonuje się przejście od abstrakcyjnych konstrukcji społecznych do rudymentarnych, dotykalnych elementów życia społecznego.

W apokryficznej wersji ewangelii stworzonej przez Michaiła Bułhakowa w jego powieści Mistrz i Małgorzata, w słynnym dialogu między Poncjuszem Piłatem a Jezusem dokonuje się niepoodziewany zwrot. Piłat pyta oczywiście „Cóż więc jest prawdą?", ale odpowiedź, jaką dostaje, jest niespodziewana:

Prawdą jest to przede wszystkim, że boli cię głowa i to tak bardzo cię boli, że małodusznie rozmyślasz o śmierci. Nie dość, że nie starcza ci sił, by ze mną mówić, ale trudno ci nawet na mnie patrzeć. Mimo woli staję się teraz twoim katem, co zasmuca mnie ogromnie. Nie możesz nawet o niczym myśleć i tylko marzysz o tym, by nadszedł twój pies, jedyne zapewne stworzenie, do którego jesteś przywiązany. Ale twoje męczarnie zaraz się skończą, ból głowy ustąpi ${ }^{17}$.

Bez trudu możemy odczytać ten fragment powieści jako niespecjalnie zawoalowaną krytykę abstrakcyjnej ideologii, która zawsze jest na służbie opresyjnej władzy. Jezus przeciwstawia splendor rzymskiej władzy logice cierpiącego ciała, która jest jedyną prawdziwą rzeczywistością.

${ }^{16}$ R. Shustermann, Myślenie ciała. Eseje z zakresu somaestetyki, przeł. P. Poniatowska, Warszawa 2016, s. 20.

${ }^{17}$ M. Bułhakow, Mistrz i Matgorzata, przeł. I. Lewandowska, W. Dąbrowski, Warszawa 2004, s. 21.

Prace Kulturoznawcze 23, 2019, nr 1

(C) for this edition by CNS 


\title{
Somesthetics, somapower, and microphysics of emancipation
}

\author{
Abstract
}

The aim of the article is to analyze the resistance to the oppressive power in the everyday life with the stress on bodily practices which become the vehicle of emancipation. The article explores two important, but never adequately researched, theoretical fields: the body as a vehicle of social critique and the relation between everydayness and politics. I would like to address these two issues by discussing the debates on them unfolding in the contemporary social sciences and humanities. This will enable me to identify the existing gaps and suggest how they could be bridged. The main argument of the article is that we need an adequate concept of the relations between the body and power, which can emerge from the pragmatist tradition, developed and improved in this respect by Richard Shusterman's neo-pragmatism.

Keywords: power, body, emancipation, everyday life, politics

\section{Bibliografia}

Boltanski L., On Critique: A Sociology of Emancipation, przeł. G. Elliott, Cambridge 2011.

Bułhakow M., Mistrz i Małgorzta, przeł. I. Lewandowska, W. Dąbrowski, Warszawa 2004.

Buruma I., The Sect That Become an Enemy of the State, „New York Times” 25 July 1999.

Engeles F., Położenie klasy robotniczej w Anglii, przeł. A. Długosz, Warszawa 1952.

Foucault M., Techniki siebie. Czym jest Oświecenie?, przeł. D. Leszczyński, L. Rasiński, Warszawa 2000.

Goldfarb J., Polityka rzeczy małych. Siła bezsilnych w mrocznych czasach, przeł. U. Lisowska, K. Liszka, A. Orzechowski, Wrocław 2012.

Leder D., The Absent Body, Chicago 1990.

Lefebvre H., Critique of Everyday Life, przeł. J. Moore, London-New York 2014.

Lemke T., Biopolityka, przeł. T. Dominiak, Warszawa 2010.

Marks K., Rękopisy ekonomiczno-filozoficzne z roku 1844, przeł. K. Jażdżewski, T. Zabłudowski, [w:] K Marks, F. Engels, Dzieła, t. 1, Warszawa 1960.

Merleau-Ponty M., Fenomenologia percepcji, przeł. J. Migasiński, M. Kowalska, Warszawa 2017.

Rabinov P., Rose N., Biopower Toda, „BioSocieties” 1, 2006.

Ricoeur P., The Political Paradox, [w:] idem, History and Truth, przeł. Ch.A. Kelbley, Evaston 2007.

Röhrig Assunção M., Capoeira. The History of An Afro-Brazilian Martial Art, London-New York 2005.

Shustermann R., Myślenie ciała. Eseje z zakresu somaestetyki, przeł. P. Poniatowska, Warszawa 2016.

Shusterman R., Odnowienie somatycznej refleksji. Filozofia ciało-umystu Johna Deweya, [w:] idem, Świadomość ciała. Dociekania z zakresu somaestetyki, przeł. W. Małecki, S. Stankiewicz, Kraków 2009.

Prace Kulturoznawcze 23, 2019, nr 1

(C) for this edition by CNS 